\title{
The Importance of the Psychiatric Hospital in Facing the COVID-19 Pandemic - Experience Report
}

\author{
Freire $\mathrm{ACC}^{1 *}$ and Moromizato $\mathrm{MS}^{2}$ \\ ${ }^{1}$ Faculdade de Medicina da Bahia - UFBA; Escola Bahiana de Medicina; Hospital Juliano Moreira/BA, Brazil \\ ${ }^{2}$ Residente de Psiquiatria do Hospital Juliano Moreira/BA, Brazil
}

*Corresponding author: Antônio Carlos Cruz Freire, MD, PhD, Faculdade de Medicina da Bahia - UFBA; Escola Bahiana de Medicina; Hospital Juliano Moreira/BA, Brazil.

Received Date: September 28, 2021

Published Date: October 07, 2021

\section{Summary}

In the context of the pandemic by COVID-19, the impact on mental health led to an increase in demand for psychiatric care. Thus, the psychiatric hospital had to promote coping strategies in order to reduce the contagion of infection among employees and patients. The Juliano Moreira Hospital, a reference in the psychiatry field in the city of Salvador-Bahia, reorganized the dynamics of its operation by developing the Contingency Plan for prevention of COVID-19, this allowed continuity in the treatment and led to a low rate of contagion during hospitalization. In the midst of difficulties, adaptation is necessary and fundamental for the assistance to be maintained.

\section{Introduction}

In January 2020, the World Health Organization (WHO), declared the emergence of a new disease caused by a virus of the coronavirus type - COVID-19. Since then, it was considered a public health emergency of international interest and in March 2020, the WHO assessed that COVID-19 was characterized as a pandemic1. In the face of biological disaster, a pandemic carries impacting consequences, both directly and as sequelae to the individual's health [1]. In psychiatric hospitals, the wards are usually crowded and they do not have structures for the pattern of isolation, patients share common spaces, they do not keep a safe distance and have poor self-care, often due to the impairment of self-pathognosis and alteration of their judgement of reality triggered by the disease $[2,3]$. Still, the use of personal protective equipment (PPE) dental to prevent contagion and spread of the virus is not very frequent [2], but strange to the eyes of the team that lacks training and previous experience in virus control [3,4]. However, it is in the psychiatric emergency that the vulnerable and suffering subject will seek guidance and care, thus it is essential to maintain the functioning of a psychiatric hospital with the maximum security that the pandemic requires.

\section{Report}

Hospital Juliano Moreira (HJM) - in the city of Salvador, state of Bahia - a reference hospital in the area, described in April 2020, developed strategies to reorganize the dynamics of hospital operation giving birth to the Contingency Plan for the prevention of COVID - 195. Thus, the measures for the confrontation required complex, urgent and dynamic strategies. To minimize the risk of hospital infection, some measures were taken: the criteria for admission to the protected wards were stricter [2,3], in addition to the reduction in time spent on hospital stay [2,3] and in the time period of family visits [2,3,6,7] (30 minutes per family member, maximum 2, once a week). In addition, early detection of symptomatic patients is important, who, being considered a suspected case of infection by COVID-19, were referred to the contact isolation module and regulated to perform the laboratory test of choice, RT-PCR by nasopharyngeal swab. 
However, the emergency continued in its full capacity to function throughout the pandemic to date. No patient was admitted with suspected COVID-19 on the infirmary and less than $2 \%$ of patients admitted in the last 12 months developed flu-like symptoms and a diagnosis of COVID-19 after psychiatric hospitalization. Such value suggests a contagion rate lower than expected for closed environments and prone to crowding, as is the case in psychiatric hospitals. There is no blockage in admissions for non-symptomatic patients. The screening of patients who seek the HJM allows classifying between symptomatic and asymptomatic, with only asymptomatic patients being admitted for full hospitalization. The contingency plan protocols were carefully followed by the care team and atypical cases were discussed with the immediate coordination/director to define the best direction.

The institution's employees were constantly instructed about the use of PPE and the carefulness needed to the psychiatric patient during the context of the pandemic. According to Technical Note No. $53(04 / 06 / 20)$, most HJM employees are considered to be at risk of medium exposure, as they are in frequent and/or close contact with potentially infected people, but who are not considered suspicious cases or confirmed COVID-19. Thus, a flow was created to expedite the removal of the symptomatic worker while performing this diagnostic test provided by SESAB, the RT-PCR by nasopharyngeal swab [8]. Several factors can make it difficult to control the spread of the new coronavirus in a psychiatric hospital. In addition to the poorly adapted infrastructure for managing infectious diseases and the difficulties that involve a lack of self-care on the part of some patients, dealing with a highly contagious virus is not part of the psychiatry team's usual routine. Therefore, the implementation of measures to help prevent intra-hospital contagion promote greater safety for professionals in the provision of healthcare and administrative services and reduce the risk of contamination among patients. With this experience, it can be seen that adaptation in the midst of difficulties demonstrates the importance of the clinical look within the universe of psychiatry.

\section{Acknowledgement}

GOVERNO DO ESTADO DA BAHIA; Secretaria da Saúde do Estado da Bahia.

\section{Conflict of Interest}

No conflict of interest.

\section{References}

1. Alves B / O / O-M. Saúde mental e a pandemia de Covid-19 | Biblioteca Virtual em Saúde MS [Internet]. Available from: https://bvsms.saude. gov.br/saude-mental-e-a-pandemia-de-covid-19/

2. Xiang Y-T, Zhao Y-J, Liu Z-H, Li X-H, Zhao N, et al. (2020) The COVID-19 outbreak and psychiatric hospitals in China: managing challenges through mental health service reform. International Journal of Biological Sciences 16(10): 1741-1744.

3. Zhu Y, Chen L, Ji H, Xi M, Fang Y, Li Y (2020) The Risk and Prevention of Novel Coronavirus Pneumonia Infections Among Inpatients in Psychiatric Hospitals. Neuroscience Bulletin 36(3): 299-302.

4. Shinn AK, Viron M. Perspectives on the COVID-19 Pandemic and Individuals With Serious Mental Illness. The Journal of Clinical Psychiatry 28: 81(3).

5. (2021) Saúde Mental e Atenção Psicossocial na Pandemia CoVID-19: Recomendações para Gestores [Internet]. www.unasus.gov.br. [cited 2021 Sep 25]. Available from: https://www.unasus.gov.br/especial/ covid19/pdf/110.

6. Li W, Yang Y, Liu Z-H, Zhao Y-J, Zhang Q, et al. (2020) Progression of Mental Health Services during the COVID-19 Outbreak in China. International Journal of Biological Sciences 16(10): 1732-1738.

7. MINISTÉRIO DA SAÚDE SECRETARIA DE ATENÇÃO PRIMÁRIA À SAÚDE NOTA TÉCNICA No12/2020-CGMAD/ DAPES/ SAPS/ MS ASSUNTO: RECOMENDACÕES À REDE DE ATENCÃO PSICOSSOCIAL SOBRE ESTRATÉGIAS DE ORGANIZAÇÃO NO CONTEXTO DA INFECÇÃO DA COVID-19 CAUSADA PELO NOVO CORONAVÍRUS (SARS-CoV-2) [Internet]. Available from: https://site.cfp.org.br/wp-content/uploads/2020/04/ notatecnica122020CGMADDAPESSAPSMS02abr2020COVID-19.pdf.pdf

8. Bahia (2020) GOVERNO DO ESTADO DA BAHIA Secretaria da Saúde do Estado da [Internet]. Available from: http://www.saude.ba.gov.br/ wp-content/uploads/2020/04/NT-n\%C2\%BA-53-de-06.04.2020-Orientacoes-Gerais-Trabalhadores-no-enfrentamento-a-pandemia-ATUALIZADA-EM-27-DE-ABRIL-DE-2020.pdf 